\title{
The Greek of Italy Between Archaism, Internal Evolution and Contact Phenomena
}

\author{
Carlo Consani \\ ("Gabriele d'Annunzio" University of Chieti and Pescara)
}

\begin{abstract}
This paper aims to provide a comprehensive overview of the Greek of Italy with regard to his dialect differentiation and long-term trends. After addresing some issues regarding the absolute and relative chronology of the Doric domain, internal lines of evolution that appear to be characterized by several peculiarities are analysed. The first area is linguistic communication with the motherland. The second is the presence of poles that have promoted linguistic standardization processes (Tarentum, Syracuse) and poles that have been affected by these processes (Rhegium, Siris, Locri). Lastly, particular attention is devoted to the analysis of the interlinguistic contact that characterized the Greek of Italy during the Hellenistic and Roman eras. In order to clarify the dynamics of this contact situation, an analysis is conducted of certain inscriptions that reveal the different types of interference with the Italic languages and Latin.
\end{abstract}

\section{Keywords}

Greek dialects; Doric; Ionian; Achaean; Latin; Magna Graecia; language contact; interference

\section{Introduction}

In the 1970 s, the person being celebrated in this memorial volume published two papers that represented - and still represent - a landmark in the study of the Greek dialects of Magna Graecia and Sicily (Bartoněk 1973, 1975): thus, this is the perfect occasion to make this tribute.

From the first half of the 1970s to present, the Greek of Italy has been the subject of several studies that have contributed to increase our knowledge of the dialects of each colony as well as many linguistic phenomena that characterised them from a synchronic and diachronic point of view; ${ }^{1}$ however, there is still a lack of an overall look at the Greek of the Magna Graecia, similar to what has been recently attempted for the Greek of Sicily. ${ }^{2}$

1 Please refer, as a non-exhaustive example, to the works by Arena $(1989,1992,1994,1998)$ and the collections by Dubois (1989, 1995, 2002, 2008).

2 I am referring to the contributions collected in Tribulato (Ed. 2012). 
The differences between the situation of Sicily and that of Magna Graecia are quite obvious: the former is much more defined and localised, while the latter is more diverse in terms of geopolitical conditions and variety of dialects; nevertheless, an attempt to analyse the Greek of Magna Graecia with the same comprehensive approach used for the Greek of Sicily could be interesting.

In order to achieve some kind of interesting results, this attempt shall comply with some requirements: first of all, it shall aim to define the general characters of the Greek of Italy and the more specific internal directions of evolution, as well as the diatopic variation; then, and as a consequence of the first requirement, it shall mainly identify and analyse the long-term phenomena; finally, with respect to the peculiarities of the linguistic scenario that characterises southern Italy from the Greek settlements through the whole Roman age, particular attention shall be paid to the phenomena caused by the inter-linguistic contact. As a matter of fact, this latter aspect represents one of the most specific features of these settlements, with the consequences resulting from the widespread phenomena of bilingualism that involved - although in different ways - most of the history of Italian Greeks, due to the long-lasting coexistence of different languages.

The very geographical location with respect to the Greek-speaking dominion of the Balkan Peninsula defines the Greek of Italy - and that of Pontus - as belonging to an area that can be considered both subsequent and lateral from a geo-linguistic point of view. It is therefore very interesting to analyse, from this perspective, both the conserved elements as regards the dialects of the motherland and the evolutions within Magna Graecia, including the degree of linguistic communication in which they took place with respect to the original counterparts, as well as the phenomena caused by the interference with the languages spoken in ancient Italy and, later, with Latin.

These three aspects will be dealt with in the three following sections of this contribution, which will be followed by an attempt to sum everything up.

\section{Archaisms and matters of relative chronology}

1.1. Overall, the Greek of Italy shows particular conservation traits due to two facts: the different absolute chronology of the colonies foundation and the fact that sometimes the epigraphic testimonies of the colonies are even older than those from the motherland. ${ }^{3}$ The following example should be enough evidence of this: $\langle y\rangle$ having the phonetic value of a close back rounded vowel, as inferred by the frequent spelling with $\langle\mathrm{Q}\rangle\rangle$ this sound had already taken up a [+front] trait since the archaic period in most of the Ionic-Attic area. ${ }^{5}$

3 For an overall picture of the Greek of Italy, Bartoněk's work is still unequalled.

4 See Bartoněk (1975: p. 27 - Cumae); Arena (1998: p. 103 - Locri).

5 With respect to the phonetic value of $\langle y\rangle$ in the Ionic-Attic context and the continental areas and pronunciation conservation [-front] of the sound, refer to Allen (1987: pp. 65-69), Petrounias (2007: pp. 549-550). 
The analysis of the archaisms compared to the motherland is even more interesting within the Doric domain, particularly of Laconian origin. If we analyse one of the most characteristic traits of Laconian, the passage from $\langle\vartheta\rangle$ to $\langle\sigma\rangle-$ phonetically from an occlusive sound with an aspiration trait $\left[\mathrm{t}^{\mathrm{h}}\right]$ to an unvoiced dental fricative $[\mathrm{s}]$, probably through an unvoiced interdental fricative sound $[\theta]$ - we can see that this phenomenon took place in Sparta only from the $4^{\text {th }}$ century B.C., but the spelling with theta was constantly used that in Tarentum and its colony Heraclea up to the Hellenistic Age. Therefore, everything would lead to believe that this phenomenon developed during a recent Laconian phase in the motherland, but it did not spread to the Taranto colony and Heraclea sub-colony because it had not yet developed when they were founded.

Thanks to some intuitions by A. C. Cassio (2002) and, more recently, an accurate demonstration by Lazzeroni (2006) we currently know that things went quite differently, as can be proven on the basis of some indirect clues from both the Greek of Greece and the Greek of Magna Graecia. As regards Greece, we have the testimony by Aristophanes who uses the trait $s$ instead of $t h$ (Lys. 1302-1313) ${ }^{6}$ in the rendition of the Laconian dialect in the Lysistrata, clearly in advance with respect to the explicit documentation on Laconian epigraphy; as regards Magna Graecia, the clues are more indirect but their concurrence leaves very few doubts: the first clue is related to the form of the hydronym $\Gamma \alpha \lambda \alpha \tilde{i} \sigma 0 \varsigma$ (Galaesus, in its Latin translation), located near Taranto, which can hardly be separated from the $-\alpha \iota \theta 0 \varsigma$ hydronymic form used in Sicily and Magna Graecia (cf. $\Sigma v ́ \mu \alpha \iota \theta o s$, Ní $\alpha \iota \theta$ ○) and that reflects a local version of $\langle\theta\rangle$ as an alveolar fricative (Cassio 2002: pp. 440-442); the second element refers to the Oscan rendition damusennia (attested in the Iuvilas from Capua) of the Greek $\delta \alpha \mu o \theta o t v i ́ \alpha$, whose cultural connections with Tarentum are well proven (Lazzeroni 2006: p. 83). The last clue comes from the Messapian, which graphically renders the substitute of $* t i$ with $\langle\tau \theta\rangle$ or even $\langle\theta\rangle$ : this shows that, as the Messapian alphabet derives from the Tarentum alphabet, when the $\langle\theta\rangle$ sign was borrowed, the system already featured a phonetic value very similar to the unvoiced dental fricative; this graphic/sound matching would then be reproduced in the target language (De Simone 1972: p. 172).

1.2. These examples are significant for several reasons: first of all, because it is only thanks to the specific situation of the Greek of Italy and one of its more typical aspects i.e. its contact and interference with the languages of ancient Italy - that we can manage to retrieve these data; the second aspect, which is also significant with respect to methodology, is the fact that the filter of writing seems to be able to hide the actual phonetic reality also in situations - such as Laconia - where there is no evidence of a particular attention to the graphical rendition of the dialect, in terms of neither accuracy nor graphic standardisation. ${ }^{7}$ Thus, this case is an example of the way in which specific characteristics of a certain variation, given the unremovable conditioning of writing, can be considered

$6 \quad$ As regards the use of Laconian by Aristophanes and the related linguistic attitudes, see Willi (2002 [2007]: pp. 139-141).

7 For the attitudes of the Spartans towards their own dialect and some enlightening comparisons with other dialects of the Greek diasystem, see Morpurgo Davies (1993: pp. 265-270). 
in a negative way so to speak, from the outside and due to the conditioning that caused the variation by contact rather than on account of a direct and explicit documentation of the dialect sources.

Similar situations, although less significant for the Greek of Italy, also characterise two other phenomena that are typical of the Laconian dialect: the aspiration of the secondary voiceless sibilant between vowels $\left([\mathrm{s}]>[\mathrm{h}] / \mathrm{V}_{-}-\mathrm{V}\right)$ and the outcome of the initial $[\mathrm{w}]$, noted with digamma, as a labial stop or labiodental fricative, noted with beta; both phenomena should be probably dated back to before the relevant graphical evidence; what these two phenomena have in common is a strong inconsistency in the written form, due to either structural (Lazzeroni 2006: pp. 84-85) or cultural reasons (Morpurgo Davies 1993: pp. 266-267), which makes it difficult to define their absolute chronology.

\section{Evolution and internal dynamics}

2.1. The first phenomenon that, from a general point of view, involves the Greek of Magna Graecia with respect to the internal dynamics is represented by the variety of dialect groups related to the colonial varieties and the mutual relationships between them.

- The Ionic dialect is clearly concentrated mostly on the Tyrrhenian coast from Capua to Rhegion (further in this paper Rhegium, today Reggio di Calabria), continuing on the coast of northern (Zancle and Himaera) and eastern Sicily (Naxos, Catania, Leontinoi - further Leontini); an isolated offspring of this dialect can be found in the isolated colony of Siris, founded in the gulf of Tarentum by the colonists coming from Micrasian Ionia, namely from Colophon.

- The colonial settlements with a Doric dialect are located around Tarentum (severior Doric type) and on the south-eastern coast of Sicily, from Selinunte to Camarina and Syracuse (mitior Doric type).

- The settlements with an Achaean dialect were more scattered and with more isolated colonies on the Tyrrhenian coast (Poseidonia and Terina), whereas, except Metapontum, the Achaean colonies on the Ionian coast were distributed continuously from Sybaris and Thurii to Croton and Caulonia.

- Finally, a virtually isolated case is represented by Locri that, as clearly shown by its name, was founded by colonists coming from the Greek continent and precisely from Opuntian Locris or Ozolian Locris. ${ }^{8}$

In general, and considering this type according to the main dialectal facies of the motherland, the two types of dialects coexisting in Magna Graecia are on the one hand Ionic (both Euboic and Micrasian) and on the other hand Doric (both severior and mitior) and north-western.

The following table shows the structural differences able to set the basis, in conditions of bilingualism, for automatic conversion phenomena, allowed in bilingual speakers by the inter-linguistic identification of the features.

8 For an overall view of the settlements, please refer to Bartoněk (1975), Arena (1999). 


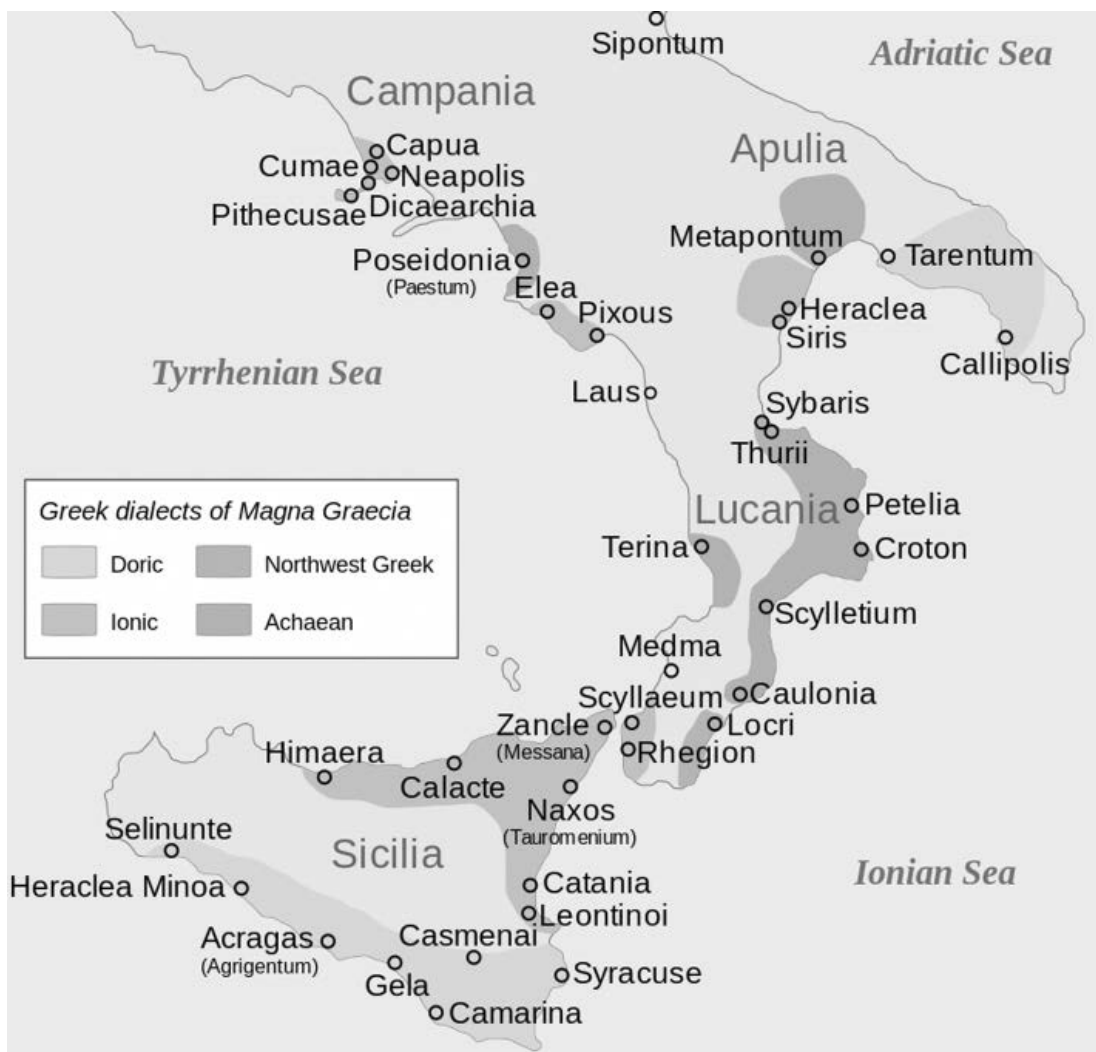

Figure 1: Greek dialects of Magna Graecia

\begin{tabular}{|l|l|}
\hline lonic type & Non-lonic type (Doric) \\
\hline 1. Early change $\mathrm{a}:>\varepsilon:$ & Conservation of $\mathrm{a}:$ \\
\hline 2. Contraction of $\mathrm{a}+\mathrm{e}(:)>\mathrm{a}:$ & Contraction of $\mathrm{a}+\mathrm{e}(:)>\mathrm{e}:$ \\
\hline 3. Contraction of $\mathrm{a}:+\mathrm{o}(:)>\mathrm{o}:$ & Contraction of $\mathrm{a}:+\mathrm{o}(:)>\mathrm{a}:$ \\
\hline 4. Assibilation $\mathrm{ti}>\mathrm{si}$ & Conservation of $-\mathrm{ti}$ \\
\hline 5. Desinence of $1^{\text {st }}$ pers. active $-\mu \varepsilon v$ & Desinence of $1^{\text {st }}$ pers. active $-\mu \varepsilon \varsigma$ \\
\hline 6. Future with $-\sigma \omega$ & Future with $-\sigma \varepsilon \omega$ \\
\hline 7. Conditional conjunction $\varepsilon \mathrm{i}$ & Conditional conjunction $\alpha \mathrm{i}$ \\
\hline 8. Modal particle $\alpha \ddot{v} v$ & Modal particle $\kappa \alpha$ \\
\hline
\end{tabular}

As we can see, the number of linguistic features that can be automatically converted by bilingual speakers is quite high and involves all the levels of the linguistic structure, with a - quite obvious - prevalence of the features related to the field of sounds (1-4), but also with significant effects on the morphological (5-6) and morphosyntactic aspects (7-8).

2.2. The historical and political relationships between the colonies caused several models of interaction between the two above mentioned types of dialect; in general, the 
cities with a Ionic dialect are more affected by the pressure from the colonies with other dialects, particularly those with a Doric dialect.

Siris and Rhegium are two perfect examples of this: Siris is the only settlement with an Ionic dialect founded in the $7^{\text {th }}$ century on the Ionian sea by colonists from Colophon and destroyed after more than one century, around $530 \mathrm{BC}$, by a confederation of the Achaean colonies of Sybaris, Croton and Metapontum; one of the few documents from this area dating back to after the above mentioned destruction was written with Achaean characters and in a non-Ionic dialect $(\tau \tilde{\alpha} \varsigma \theta \varepsilon \bar{o})$, proving that the military defeat suffered by Siris also brought changes to the culture and dialect.

The situation of Rhegium is very similar, although better documented, and I have dealt with it in a work that will be used here as a source for the most significant data related to the issue at hand (Consani 1995b).

After an archaic phase that, in spite of the scarce documentation shows clear Ionic features, ${ }^{9}$ the start of the $4^{\text {th }}$ century BC represents a clear break in the history of the town from a linguistic and political point of view: as a matter of fact, in $387 / 6 \mathrm{BC}$, the town lost its independence after the siege and destruction by Dyonisius I, tyrant of Syracuse, and over the following century and a half its subordination to the culture and politics of the main centres of Doric Sicily was increasingly clear. ${ }^{10}$ In this historical stage, Rhegium showed a strong pro-Roman attitude, which led to Rome providing a military garrison - mainly formed by soldiers from the Campania region - to face the threats made by Pyrrhus and Carthaginians (c. 280 BC); this policy would be rewarded ten years later, when the Romans punished by death or expulsion the garrison from Campania that illegally took over the political power (Meister 1987: pp. 84-86).

Also in this case, along with the loss of independence and other political events, there must have been a sharp change in the town's dialect that, due to the lack of documentation, was fully documented only as of the start of the $2^{\text {nd }}$ century BC, in the decree issued by the town in favour of the Roman praetor Cneus Aufidius: ${ }^{11}$ as I have tried to prove, this text shows a linguistic background that clearly complies with the characteristics of the Ionic-Attic koine with a Doric facies as regards the phonetics, characterised by

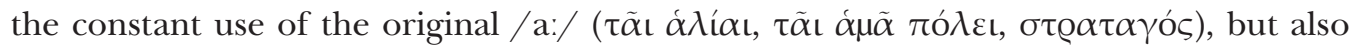

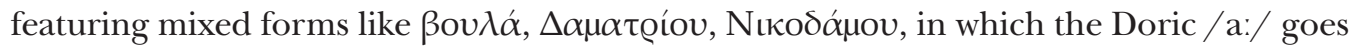
along with the $\langle\mathrm{OY}\rangle$ of the isovocalic contraction, typical of the Ionic-Attic koine. ${ }^{12}$ This sharp turn from the original Ionic type towards a mitior Doric koine with a clear Syracusean origin can be found, although with increasingly fewer proofs, in the documentation dating back to the Roman age.

9 On this aspect, please refer to Arena (1994: nn. 58-71 and related linguistic comment).

10 See Meister (1987), Costabile (1978, 1979).

11 IG XIV, 612 = Ditt. Syll. 3, 715. For the historical significance of this text, please refer to Turano (1968: pp. 100-105) and Costabile (1978: pp. 47-49); for a detailed linguistic analysis, see Consani (1995b: pp. 196-197).

12 For the particular local colour of this linguistic form and an analysis of the other linguistic phenomena, please refer to the above mentioned Consani (1995b: pp. 195-197). 
2.3. An even more complex situation - from a synchronic and diachronic perspective and for the aspects related to the inter-linguistic contact - is represented by the dialect of Locri, the only place on the Italian territory with a dialect belonging to the group of continental and north-western Doric dialects, as already mentioned briefly above.

In the analysis of the documentation related to the dialect of Locri - made even more interesting and significant, as well as more complex, by the Olympieion tablets - we can see a recurring attempt to connect this dialect facies to a severior Doric Greek: the most ancient attempt (as far as I know) dates back to the Sammlung by Collitz \& Bechtel (vol. I, no. 1658), while the most recent one to Blomqvist (1975); Bartoněk's suspension of judgment (1975: pp. 34-35) on this matter ${ }^{13}$ is revealing of the complexity of the situation.

However, I think it is possible to say something more, mainly negative: as a matter of fact, the projection to the prehistoric age of the severior vowel system that characterises the documentation from the $5^{\text {th }}$ and $4^{\text {th }}$ century is not supported by any kind of evidence and gives too much significance only to the aspects related to the vowel system, neglecting other phenomena (Consani 1995a: pp. 78-79).

Given the existing documentation related to the Locri dialect, which does not allow to go back past the classical age, the interpretation of the structural data must be naturally and necessarily integrated with external data. In the perspective of connecting the internal and external history of this dialect with a cause-effect connection, we have to face a problem: considering the dialect as originally belonging to the severior Doric type, we should identify the source that introduced different features, which prevailed in quantity during the classical age; on the other hand, if we consider the ancient sources that relate the foundation of the settlement with the Locris region, thus with a passage from Doric and north-western dialects quite different from the severior facies of Peloponnesian Doric, we should be able to identify the source that caused the Locri dialect to take its severior vowel system in the documentary age.

Obviously, from a methodological point of view, considering this double possibility means shifting the matter from an exclusively genetic approach to an approach that also considers the dynamics related to the interference by contact.

Now, given the difficulty of identifying a source for the irradiation of the typical features of north-western dialects in this part of Magna Greacia and at the end of the classical age, we still need to take into careful consideration the other alternative, i.e. identifying a source of irradiation of the severior vowel system; however, if we consider this matter in this way, the answer is immediate and absolutely obvious: several clues allow to identify Tarentum and its colony Heraclea as the origin for the spreading of this feature. As a matter of fact, at that time, Tarentum had a leading role in guiding the Italiot league during the conflicts with the neighbouring populations - Messapians, Bruttii and Lucanians - and, between the late $4^{\text {th }}$ century and the early $3^{\text {rd }}$ century BC, in contrasting the Roman expansion in this area (De Juliis 2004: pp. 71-86). The tablets of the Olympieion of Locri date back to this phase of the political activity of Taranto and the $\beta \alpha \sigma \lambda \varepsilon \dot{u} \varsigma$ quoted in several tablets allows to identify Pyrrhus, king of Epirus and an

13 For a detailed analysis of the Locri dialect in terms of inter-dialectal classification, please refer to Consani (1995a: pp. 77-79). 
ally of Tarentum against Rome (De Franciscis 1972: pp. 78-84; Musti 1979: pp. 212-215): therefore, this defines the context in which we can assume the introduction of dialect features from Tarentum into Locri. ${ }^{14}$

In the light of this, the dialect of Locri becoming more similar to Doric due to the influence of Tarentum appears justified by external data and manages to provide a more effective solution to the classification problems of this dialect: it should be taken back to its traditional north-western origin (also in accordance with the type of alphabet that shows clear connections with the one used in the Locris region) and, in a period of time not far from when these texts were written, it took the five-vowel system with severior-type long vowels.

2.4. The above mentioned cases are perfect examples of the character of the linguistic history of the Magna Graecia colonies during the Hellenistic period, a character definitely marked by internal and external dynamicity; apart from the greater vitality of the Doric type compared to the Ionic type (almost everywhere being recessive), I believe the most important element is represented by the co-existence of standardised and standardising centres: the former include, as we have seen, Rhegium - which abandoned its original Ionic character and took on a mitior Doric type of Syracusean origin - and Locri - taking on significant severior features from Taranto. The two standardising centres, which represented the focus of linguistic convergence phenomena, are represented by Tarentum and Syracuse - the first with a severior Doric dialect and the second with a mitior Doric dialect - whose function would soon be terminated by the Roman conquest of the scene and the area. ${ }^{15}$

These two initial forms of Doric linguistic standardisation were affected by the IonicAttic koine, whose presence in Magna Graecia was already detectable in the $4^{\text {th }}$ century $\mathrm{BC}$ - and in the two most representative sets of documentation, i.e. the tables of Heraclea and Locri ${ }^{16}$ - and gradually increased over the two following centuries: the interference between these two types of Greek created a specific koine of the Italiot area, which can be described as a basically Doric koine with a more or less deep Ionic-Attic interference: this is probably the remote basis for the introduction of some Doric features into the modern Greek of Italy.

The mutual diastratic arrangement of the Doric and the koine components surely still needs to be defined. While the assumption I once made about the koine circulating via socially low channels still needs to be thoroughly verified, ${ }^{17}$ it is however necessary to

14 Ancient sources inform us about the alliance between Locri and Pyrrhus and about the town siding with the anti-Roman faction led by Tarentum, before finally hosting a Roman garrison after 275 BC, when Pyrrhus, defeated by the Romans, left Italy forever (Niutta 1979: p. 270).

15 The influence of Syracuse on the neighbouring towns in the area of the strait and up to the Bruttii's territory ended with the death of the tyrant Agathocles in 289; similarly, the role of Tarentum ended with the establishment of a Roman garrison in $270 \mathrm{BC}$ and the town became socia of Rome (De Juliis 2004: pp. $80-86)$.

16 For the penetration of the koine into the documentation of Magna Graecia and Sicily in the Hellenistic and Roman age, see Consani (1995a, 1996).

17 Please refer to Mimbrera (2012: p. 227, n. 16). 
stick to the currently available material data, which are represented by two distinct but complementary observations: the first one refers to the fact that the continuity of the Doric component until the late Roman age can only be explained by considering this dialect facies as a variety natively spoken by the local population; on the other hand, if this assumption is correct, this fact does not automatically imply that the penetration of the Ionic-Attic koine should be ascribed to different channels that are diastratically different from those of the language spoken by Greek-speaking people. However, this matter definitely needs to be studied more in depth, also because - as illustrated in the next paragraph - the types of koine that were documented in this area during the Roman age were characterised by definite non-standard features.

\section{Phenomena of interference by contact}

The types of contact that characterise Greek in Sicily have already been analysed by me in a paper some years ago (Consani 2006a) and I am glad to see that many results of that analysis are now included in the above mentioned monograph on the languages and inter-linguistic contact in Sicily. ${ }^{18}$

As said before, the Greek of Magna Graecia, like that of Sicily, is characterised by an extended condition of inter-linguistic contact with Italic populations of Samnite origin and other of Oscan origin, such as the Brettii, as well as the Messapians, the Iapygians and, later on, with the Latin language brought by the Roman conquest of the whole ancient Italy; for the time being, I shall not consider the Etruscans and Carthaginians, considered by the Greeks as definitely different from a linguistic and cultural point of view. ${ }^{19}$

Rather than dealing with this matter comprehensively and generally, which surely is not the point of this paper, I believe that the best way to have an idea of the depth, chronological extension and variety of forms of contact that affected the Greek of Magna Graecia is the analysis of the texts that are significant with respect to this. I shall refer to some texts that I consider to be particularly significant and that I have already studied before, because I believe that a comprehensive analysis of them can provide important elements to evaluate the long-term trends and evolution directions that are the subject of this observation.

3.1. The first case that I think is worth mentioning takes us back to the Bruttium region between the late $4^{\text {th }}$ century and the early $3^{\text {rd }}$ century BC, i.e. to a geo-linguistic situation in which the Greek language, penetrated inland along the lines of communication with the Ionian and Adriatic coasts, was in contact with the indigenous population of the Brettii and, shortly after, with Latin. ${ }^{20}$ This linguistic and cultural context originated the inscription on the gold crown of Armento, a text that was rather uncomfortably dealt

18 Tribulato (Ed. 2012); in particular, please refer to the chapter on the Latin language used for the inscriptions in the most ancient period (Tribulato 2012: spec. pp. 305-315).

19 For an overall historical view, please refer to De Juliis (2004); also Poccetti (Ed. 1988), Poccetti (2005).

20 For the local situation and the identity of the Bruttii in particular, please refer to Poccetti (Ed. 1988). 
with by all the scholars who handled it since the 1970s; $;{ }^{21}$ this discomfort also led to unjustified integrations to the text that, on the other hand, is perfectly legible and sounds like:

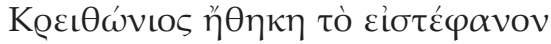

The text means, quite simply, "Kritonios, dedicated the crown", i.e. the gold crown that features this inscription.
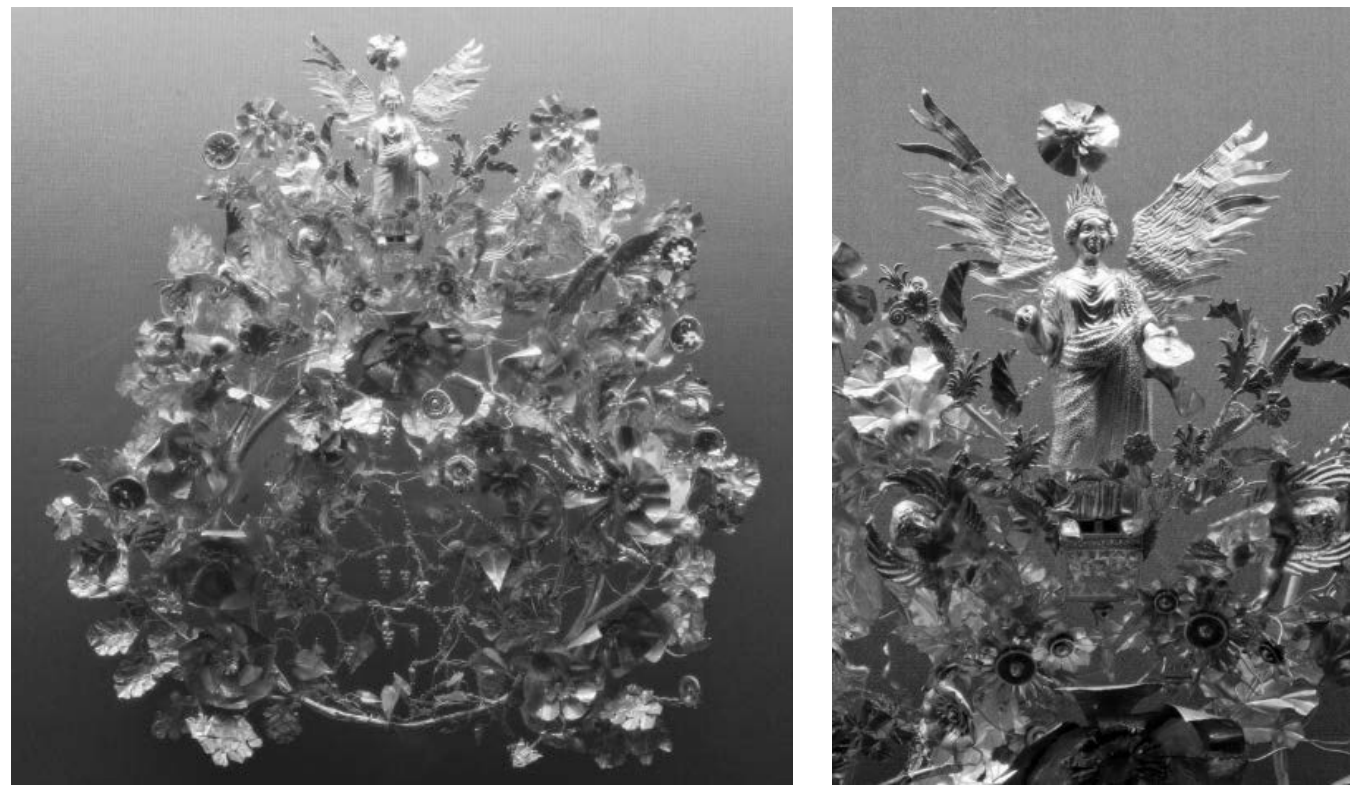

Figures 2 and 3: The gold crown from Armento

I believe that I have already shown ${ }^{22}$ that most of the above mentioned interpretation problems depend on the analysis of the text based on the standard Ionic-Attic coeval koine, which prevents the appropriate appreciation of the linguistic features included in the short inscription: first of all, the iotacism revealed by the $\langle\varepsilon \iota\rangle \sim\langle$ ı $\rangle$ exchange, showing the phonetic match of $[\mathrm{e}:]$ and $[\mathrm{i}(:)]$; then, the free oscillation between the graphic signs of eta and epsilon in words show little sensitivity to the vowel quality, although $[\varepsilon:]$ had not merged into $[i(:)]$ yet. These elements are already clues of a type of Greek that was characterised from a diachronic point of view and are combined with two other significant features: the vowel prosthesis - graphically $\langle\varepsilon \downarrow$, phonetically [i] - in front of the group $s C$ and the omission of the final nasal sound of the article. As regards

21 A summary of the studies carried out on this text in Consani (2006b: pp. 208-209).

22 A detailed analysis of this text in Consani (1996: pp. 116-118). 
the first feature, the Greek language developed forms of vowel prosthesis before $s C$ both in Asia Minor and in Magna Graecia, most probably due to the contact and interference with the languages that feature the same phenomenon (Consani 1999b): a situation of contact would have caused what is defined a "boost effect" of latent trends in different linguistic systems, that are boosted and surfaced by the contact; the principle originally uttered by Weinreich in 1953 was confirmed by a significant amount of data from the most diverse contexts (Heine \& Kuteva 2006). As regards the second feature, the omission of the final nasal sound, we are dealing with a well-known phenomenon that was initially typical of the sub-standard Attic and then of the Hellenistic Greek, when the fall of this sound becomes more general.

If we combine all these elements, also adding - from a semantic point of view - the use of the simple verb $\varepsilon^{\prime} \theta \eta \kappa \varepsilon$ instead of the standard $\alpha \dot{\alpha} \varepsilon \eta \uparrow \kappa \varepsilon$, we can have a picture of the particular type of Greek produced by the external circumstances described in the beginning: with features due to the interference by contact, a kind of Greek that was very different from the standard and consistent with the evolution of the vowel system of the koine. If the author was local, as indicated by the stylistic clues of the artefact, and if the author also made the inscription, we could assume that it was a native speaker of Oscan using Greek as L2 or LS, clearly considering it as a prestigious linguistic code, to make the inscription on an artefact of great economic and artistic value, thus related to the local elite.

3.2. A very complex interference case where the main role is played by Greek and Latin is the inscription on the large tile placed as a cover to a tomb, found in 1975 in Occhio di Pellaro, about ten kilometres south of Rhegium. It is a set of four different texts characterised by different writers' blocks and carved with different directions on the support.

I

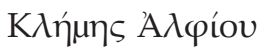

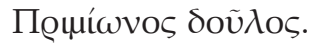

II

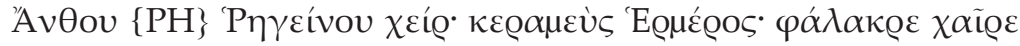

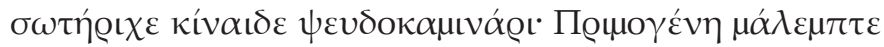

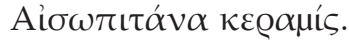

III

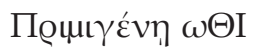

TA $\tau \tilde{\omega} \mu \alpha \lambda \eta \dot{\mu} \mu \tau-$

$\pi \tau \omega \mathrm{KATTA \Gamma}$

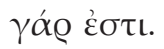

IV

Пещо. 
Apart from the interpretation difficulties of the second and third texts, for which please refer to Consani (1995b: pp. 200-201), a set of linguistic clues can be obtained by this set with respect to both Latin and Greek and to the interference phenomena. With respect to Latin, aspects like the missing nasal sound /__s\# hint to a non-standard language type, regardless that such difference should be considered as non-urban or diastratically low (in accordance with the servant status of the character of the first epitaph) or archaic (if the tile dates back to the $3^{\text {rd }}$ century BC; Consani 1995b: p. 201).

With respect to Greek, it is important to notice a iotacism condition that is not very different from the previous case, with $\langle\varepsilon \triangleright$ representing [i], but with eta used to express

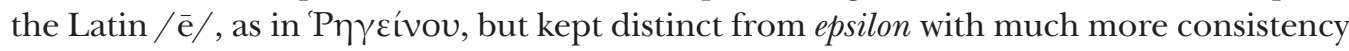
than in the Armento inscription.

However, the most interesting aspects are the interference phenomena between the two systems, affecting deep layers of the linguistic articulation, such as derivative and compositional morphology.

First of all, the compound $\mu \alpha \dot{\alpha} \lambda \mu \pi \tau \tau o s$, which is a form of grammaticalization of the Latin expression male emptus, fixed in a compound with an inflected morphology typical of the themes in -0 -.

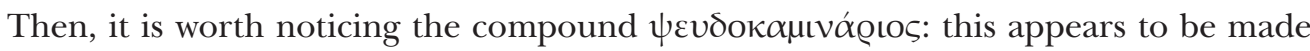
with material of Greek origin that must have passed to Latin quite soon, as shown by the Plautine Pseudolus with respect to the initial element; all this shows the degree of integration of this loanword into the Latin system back in the archaic age, up to the point of adding the Latin suffix -arius, inflected in the vocative following the example of filius.

This picture, already significant of the degree of intertwining of the two codes in con-

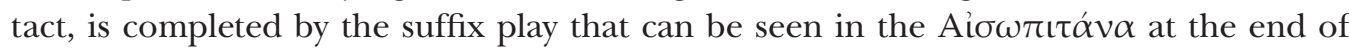

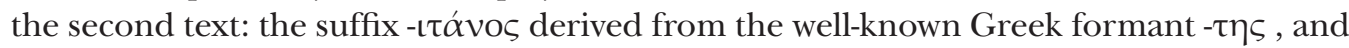
here used in its Doric form $-\tau \alpha \varsigma$, is followed by the Latin suffix $-a n-o^{\circ}$. In the light of this mixed formation, it is interesting to wonder about the value of the final $-\alpha$; being a sin-

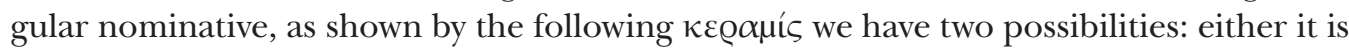
a Latin nominative with Greek spelling or, if the word is inflected according to Greek, it would represent evidence of a Doric form, which would be incredibly valuable given the scarceness of such forms in this area in the $3^{\text {rd }}$ century BC (cf. $\S 2.2$.).

In general, the texts carved onto the tile of Pellaro clearly show that, in spite of choosing the Greek spelling to write this text - which is a clear cultural clue of how Greek writing was considered prestigious at that time in that area, the Latin linguistic skill of the writer of these texts is not lower than his Greek skill: this represents an extremely interesting clue, considering the period of time. Along with the Greek-Latin contact, we should not forget the indigenous element, which is also quite clear in this text as shown by the typical Italic name, although correctly spelled in Greek, of Alphios Primion, the master of the slave celebrated in the first inscription.

3.3. The intertwining of Latin and Greek into a cultural background of Italic origin must have been long, despite the increasing Romanization of southern Italy; as a matter of fact, also during the imperial age, we can still find examples of koine rich in spoken traits 
hinting at a condition of linguistic vitality that definitely exceeds the mere reproduction of typical epigraphical formulas.

A similar situation can be seen in the funeral inscription of Fabia Sperata and Sallusti(u)s Agathocles (IG XIV 626), dating back to the $2^{\text {nd }} / 3^{\text {rd }}$ century CE, quoted by Rohlfs (1979: pp. 7-8) for the passage from Latin in the initial part to Greek in the last two lines:

D M

FABIA SPERATA

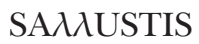

AGATHOC $\lambda$ ES

OCAERO[DI]OS

ATOIC $\mathrm{PO}[\varepsilon] \mathrm{CAN}$

"For the Supreme Gods. Fabia Sperata, Sallustis Agathocles, the Rhodian, made them for themselves."

First of all, the whole sentence represents a mixed language text in which, apart from the names of the two people written in Latin, the rest is written in Greek.

Then, the two writing systems are hardly kept distinct (lambda also in the Latin text, but $\langle\mathrm{c}\rangle$ instead of $\langle\mathrm{k}\rangle$ and $\langle\mathrm{R}\rangle$ instead of $\langle\mathrm{P}\rangle$ in the Greek text).

Finally, from a linguistic point of view, it is necessary to observe a very significant set of interferences and specific features:

- Sallustis reproduces the typical evolution of the spoken koine, where the suffixes -ios/-ion are reduced to -is/-in;

- $\quad<\mathrm{CAE}>$ represents the conjunction $\kappa \alpha$ í and phonetically is similar to the monophthongised pronunciation $\langle\kappa \varepsilon\rangle$;

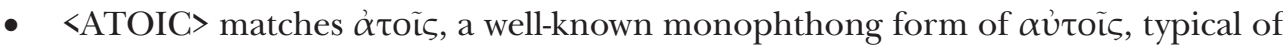
the Roman age koine, which could have been brought to light also thanks to the contact with the similar trend of late/sub-standard Latin (Augustus > it. agosto).

\section{Discussion and conclusions}

The cases of interference between the two codes could easily be multiplied and extended to other types of contact and languages involved in contact: an example is the paradigmatic case of Petelia and the new defixio brought to light in this town (Lazzarini 2004) and thoroughly analysed by Paolo Poccetti with respect to the relationship and interferences between Oscan and Greek (Poccetti 2014).

However, as the perspective of this paper is more about quality than quantity, I believe that the material analysed until now is enough to make a summary of the typical aspects that characterise the Greek of Magna Graecia in general and with respect to long-term phenomena.

The first element that can be detected from the various types of phenomena analysed is represented by the fact that, in accordance with what is theoretically expected based 
on the characterization of the linguistic phases attested in the lateral and later areas, the Greek of Italy actually shows some archaic traits that in some cases manage to explain the diachrony of motherland Greek; with this respect, it is worth reminding the backdating of some Laconian phenomena, which was possible thanks to the evidence collected from colonial Greek and the relevant phenomena of interference with the neighbouring languages.

Another and equally interesting element is the internal dynamics within the Magna Graecia that, thanks to the historical events and power-based relationships, had the Ionic component behaving recessively almost everywhere compared to the Doric one, both in Magna Graecia and in Sicily. This was obviously reflected on the language as, apart from the replacement of a dialect with another in the diachrony of the individual colonies (Rhegium from Ionic to Doric, Siris from Ionic to Achaean, Locri from mitior to severior Doric), it allows to identify Tarentum on the continent and Syracuse in Sicily as two centres that had a function of linguistic convergence and standardisation of their severior and mitior varieties, thanks to their political status between the $4^{\text {th }}$ and $3^{\text {rd }}$ centuries BC: this process might have set the basis for the creation of several actual dialect koinai if it had not been interrupted by the following Roman penetration, which brought Latin to the highest level of the linguistic repertories in this area.

However, the vitality of the Greek of Italy lasted a long time also in competition with Latin, as shown by the last case examined in 3.3., and constantly communicating with motherland Greek: this is revealed by the presence of the Ionic-Attic koine, which can be perceived even from the documentation of the $4^{\text {th }}$ century $\mathrm{BC}$; the interaction of the koine with the various types of Doric dialects led to the creation of a specific local language, whose most recognisable trait is the Doric with respect to phonetics, although in morphosyntactic structures that are consistent with the evolution of the spoken koine of the Roman age and its regional differences. About this variety, we can make two observations that show all the specificity of the Greek of Italy in its extreme evolution up to the christian age: the first one is related to the fact that the koine directly or indirectly documented in the epigraphic documentation of the Hellenistic and Roman age has definitely different features from the forms of the standard Hellenistic koine, and it is characterised by traits that are typical of the spoken language and by the presence of aspects that anticipate the following evolutions. This can suggest the presence of a bilingualism or bi-dialecticism diastratically low and relevant at the level of spoken language, whose prototypical poles are the Doric koine of Magna Graecia on the one hand and forms of sub-standard spoken Ionic-Attic koine on the other hand.

The second observation refers to the fact that this picture has significant effects with respect to neo-Greek: as a matter of fact, the possible continuity of the Greek of Calabria, ${ }^{23}$ with respect to an ancient Greek phase characterised by a Doric dialect, does not need an obligated and vaguely anti-historical reference to the archaic and classic Doric nature

23 I am mainly referring to the neo-Greek of Calabria, because the one from Salento - at least in the perspective of the most recent works - apparently shows a general situation and issues that are not completely similar to the situation of Calabria: with this respect, please refer mainly to Franceschi (1973) and Fanciullo (1991, 1993), even if an early approach was also in Parlangeli (1953). 
of the Italiot colonies, but it can be more pertinently referred - from a chronological and linguistic point of view - to the Doric traces conveyed by a Roman age koine, which would take its dialect aspects due to the contact with the Italiot Dorians between the $3^{\text {rd }}$ century BC and $1^{\text {st }}$ century AD.

In fact, this type of documentation is consistent with some Sicilian magical documents dating back to the late-ancient age (Consani 1999a), also including coexisting Doric and late spoken koine elements: this should represent the final documentation attesting the continuity of the forms of interference that were typical of the Roman age before the lack of documentation that involves the whole Greek-speaking area between the $6^{\text {th }}$ and $10^{\text {th }}$ centuries; this linguistic situation shall be the starting point to trace the development that led to the emergency of medieval Greek, according to an already briefly mentioned methodology, although not thoroughly performed by scholars such as Comparetti ${ }^{24}$ or Tsopanakis (1978).

\section{Bibliography}

Allen, S. W. (1987). Vox Graeca (3. ed.). Cambridge: Cambridge University Press.

Arena, R. (1989). Iscrizioni greche arcaiche di Sicilia e Magna Grecia. Iscrizioni di Sicilia, I: Iscrizioni di Megara Iblea e Selinunte. Milano: Cisalpino-Goliardica.

Arena, R. (1992). Iscrizioni greche arcaiche di Sicilia e Magna Grecia. Iscrizioni di Sicilia, II: Iscrizioni di Gela e Agrigento. Milano: LED.

Arena, R. (1994). Iscrizioni greche arcaiche di Sicilia e Magna Grecia, III: Iscrizioni delle colonie euboiche. Pisa: Nistri-Lischi.

Arena, R. (1998). Iscrizioni greche arcaiche di Sicilia e Magna Grecia, V: Iscrizioni di Taranto, Locri Epizefiri, Velia e Siracusa. Alessandria: Edizioni dell'Orso.

Arena, R. (1999). La colonizzazione greca d'Occidente: i dialetti. In G. Pugliese Carratelli (Ed.), I Greci in Occidente (pp. 189-200). Milano: Bompiani.

Bartoněk, A. (1973). Greek Dialects of Archaic Sicily. Their Integration Tendencies. Graecolatina et Orientalia, 5, 71-89.

Bartoněk, A. (1975). Greek Dialects of Ancient Appennine Peninsula. In J. Češka (Ed.), Classica atque mediaevalia Jaroslao Ludvikovský octogenario oblata (pp. 17-36). Brno: Universita J. E. Purkyně, Filosofická fakulta.

Blomqvist, J. (1975). The Dialect of Epizephyrian Locri. Opuscula Atheniensia, 11, 17-35.

Cassio, A. C. (2002). Il dialetto greco di Taranto. In Taranto e il Mediterraneo. Atti del XLI Convegno di Studi sulla Magna Grecia (pp. 435-466). Taranto: Istituto per l'archeologia della Magna Grecia.

Comparetti, D. (1916). Le tabelle testamentarie delle colonie achee della Magna Grecia. Annali della Scuola Archeologica di Atene, 2, 219-246.

Consani, C. (1995a). I dialetti greci in età ellenistica e romana: la documentazione epigrafica della Magna Grecia e di Sicilia. In P. Cuzzolin (Ed.), Studi di linguistica greca (pp. 73-89). Milano: Franco Angeli.

24 I am referring to the well-known essay on the testamentary tables of the Achaean colonies of Magna Graecia, featured in the Annali della Scuola Archeologica di Atene (Comparetti 1916). 
Consani, C. (1995b). Per la storia linguistica di Reggio e dello Stretto in età ellenistica e romana. In R. Ajello, \& S. Sani (Eds.), Studi linguistici e filologici in onore di Tristano Bolelli (pp. 193-205). Pisa: Pacini Editore.

Consani, C. (1996). Koinai et koiné dans la documentation épigraphique de l'Italie méridionale. In C. Brixhe (Ed.), La koiné grecque antique II. La concurrence (pp. 113-132). Paris: De Boccard.

Consani, C. (1999a). Considerazioni su testi magici siciliani vecchi e nuovi. In A. C. Cassio (Ed.), KATÀ DIÁLEKTON. Atti del III Colloquio Internazionale di Dialettologia Greca (pp. 215-232). Napoli: Ist. Univ. Orientale.

Consani, C. (1999b). Sulla protesi di i__sC in greco. In P. Berrettoni (Ed.), Varietà linguistiche nella storia della grecità. Atti del Terzo Incontro Internazionale di Linguistica Greca (pp. 77-91). Alessandria: Edizioni dell'Orso.

Consani, C. (2006a). Il greco di Sicilia in età romana: forme di contatto e fenomeni di interferenza. In R. Bombi et al. (Eds.), Studi linguistici in onore di Roberto Gusmani (pp. 467-481). Alessandria: Edizioni dell'Orso.

Consani, C. (2006b). Per una visione variazionistica del greco antico. In N. Grandi, \& G. Iannaccaro (Eds.), Zhi. Scritti in onore di Emanuele Banfi in occasione del suo $60^{\circ}$ compleanno (pp. 201-213). Roma-Cesena: Caissa.

Costabile, F. (1978). Strateghi e assemblea nelle POLITEIAI di Reggio e Messana. Klearchos, 20, 19-57.

De Franciscis, A. (1972). Stato e società in Locri Epizefiri. L'archivio dell'Olimpieion locrese. Napoli: Libreria Scientifica Editrice.

De Juliis, E. M. (2004). Greci e Italici in magna Grecia. Roma-Bari: Laterza.

De Simone, C. (1972). La lingua messapica: tentativo di una sintesi. In Le genti non greche della Magna Grecia. Atti dell’XI Convegno di Studi sulla Magna Grecia (pp. 125-201). Taranto: Istituto per l'archeologia della Magna Grecia.

Dubois, L. (1989). Inscriptions grecques dialectales de Sicile: contribution à l'étude du vocabulaire grec colonial. Roma: École Française de Rome.

Dubois, L. (1995). Inscriptions grecques dialectales de Grande Grèce. Tome 1: Colonies eubéennes, colonies ioniennes. Emporia. Genève: Droz.

Dubois, L. (2002). Inscriptions grecques dialectales de Grande Grèce. Tome 2: Colonies Achéennes. Genève: Droz.

Dubois, L. (2008). Inscriptions grecques dialectales de Sicile (Vol. 2). Genève: Droz.

Heine, B., \& Kuteva, T. (2005). Language Contact and Grammatical Change. Cambridge: Cambridge University Press.

Lazzarini, M. L. (2004). Lamina plumbea iscritta da Petelia. Mediterraneo Antico, 7, 673-680.

Lazzeroni, R. (2006). Il dialetto di Sparta fra cedimento e restaurazione. Incontri Linguistici, 29, 83-89.

Meister, K. (1987). Problemi di storia dello Stretto dal Iv secolo A.C. all'inizio della prima guerra punica. In Lo Stretto crocevia di Culture. Atti del XXXVI Convegno di Studi sulla Magna Grecia (pp. 73-92). Taranto: Istituto per l'archeologia della Magna Grecia.

Mimbrera, S. (2012). The Sicilian Doric Koina. In O. Tribulato (Ed.), Language and Linguistic Contact in Ancient Sicily (pp. 223-250). Cambridge: Cambridge University Press.

Morpurgo Davies, A. (1993). Geography, History, and Dialect: The Case of Oropos. In E. Crespo, 
J. L. García Ramón, \& A. Striano (Eds.), Dialectologica Graeca. Actas del II Coloquio Internacional de Dialectología Griega (pp. 237-279). Madrid: Ediciones de la Universidad Autónoma.

Musti, D. (Ed.). (1979). Le Tavole di Locri. Atti del Colloquio. Roma: Edizioni dell'Ateneo \& Bizzarri. Niutta, F. (1979). Le Fonti letterarie e epigrafiche. In D. Musti (Ed.), Le Tavole di Locri. Atti del Colloquio (pp. 253-346). Roma: Edizioni dell'Ateneo \& Bizzarri.

Petrounias, E. B. (2007). The Pronunciation of Ancient Greek. Evidence and Hypotheses. In A. F. Christidis (Ed.), A History of Ancient Greek from the Beginnings to Late Antiquity (pp. 545-555). Cambridge: Cambridge University Press.

Poccetti, P. (Ed.). (1988). Per un'identità culturale dei Brettii. Napoli: Istituto Universitario Orientale. Poccetti, P. (1998). Lingua e cultura dei Brettii. In P. Poccetti (Ed.), Per un'identità culturale dei Brettii (pp. 3-158). Napoli: Istituto Universitario Orientale.

Poccetti, P. (2005). Il declino (o i presunti declini) della Magna Grecia, aspetti della fenomenologia linguistica. In Tramonto della Magna Grecia, Atti del XLIV convegno di studi sulla Magna Grecia (pp. 77-159). Taranto: Istituto per l'archeologia della Magna Grecia.

Poccetti, P. (2014). Bilingues Bruttaces. Il plurilinguismo di una città della Magna Grecia attraverso i suoi testi: il Caso di Petelia. In R. Giacomelli, \& A. Robbiati Bianchi (Eds.), Le lingue dell'Italia antica oltre il latino: lasciamo parlare i testi (pp. 73-109). Milano: Istituto Lombardo di Scienze e Lettere.

Rohlfs, G. (1979). L'antico ellenismo nell'Italia di oggi (sostrati e riflessi). In Le iscrizioni prelatine in Italia. Colloquio Linceo (Roma 14-15 marzo 1977) (pp. 7-28). Roma: Accademia Nazionale dei Lincei.

Tribulato O. (Ed.). (2012). Language and Linguistic Contact in Ancient Sicily. Cambridge: Cambridge University Press.

Tribulato, O. (2012). Siculi bilingues? Latin in the inscriptions of early Roman Sicily. In O. Tribulato (Ed.), Language and Linguistic Contact in Ancient Sicily (pp. 291-325). Cambridge: Cambridge University Press.

Tribulato, O. (Ed.). (2012). Language and Linguistic Contact in Ancient Sicily. Cambridge: Cambridge University Press.

Tsopanakis, A. G. (1978). Echi classici nel greco della Magna Grecia Bizantina. In Magna Grecia Bizantina e tradizione classica. Atti del XLIV convegno di studi sulla Magna Grecia (pp. 175-192). Taranto: Istituto per l'archeologia della Magna Grecia.

Turano, C. (1968). Note di epigrafia classica III. Klearchos, 10, 97-108.

Weinreich U. (1953). Languages in Contact. London-The Hague-Paris: Mouton.

Willi, A. (2002). Languages on Stage: Aristophanic Language, Cultural History, and Athenian Identity. In A. Willi (Ed.), The Language of Greek Comedy (pp. 111-149). Oxford: Oxford University Press.

Prof. Carlo Consani / carlo.consani@unich.it

Department of Modern Languages, Literatures and Cultures

"Gabriele d'Annunzio" University of Chieti and Pescara

Viale Pindaro, 42, 65127 Pescara, Italy 
